\title{
PSS Contracts for Rail and Road Infrastructure
}

\author{
Sofia Lingegård, Mattias Lindahl and Niclas Svensson
}

\section{Linköping University Post Print}

N.B.: When citing this work, cite the original article.

Original Publication:

Sofia Lingegård, Mattias Lindahl and Niclas Svensson, PSS Contracts for Rail and Road Infrastructure, 2011, Functional Thinking for Value Creation. Proceedings of the 3rd CIRP International Conference on Industrial Product Service Systems, Technische Universität Braunschweig, Braunschweig, Germany, May 5th-6th, 2011, 291-296.

http://dx.doi.org/10.1007/978-3-642-19689-8_51

(C) 2011 MediaSpringer-Verlag Berlin Heidelberg http://link.springer.com/

Postprint available at: Linköping University Electronic Press http://urn.kb.se/resolve?urn=urn:nbn:se:liu:diva-70261 


\title{
PSS Contracts for Rail and Road Infrastructure
}

\author{
Sofia Lingegård, Mattias Lindahl and Niclas Svensson \\ Department of Management and Engineering, Linköping University, Linköping \\ Sweden
}

\begin{abstract}
The productivity development for rail and road infrastructure has been weak a long time; and explanation can be found in the traditional contracts used, with little room for incentives for innovation. This literature study investigates the use of the few realized PSS contracts within the rail and road infrastructure. The descriptions and the scientific reports are on a synoptic level and a majority of the reports are funded by the involved actors, showing that there is an interest for PSS contracts in the industry and indicating significant potential for further research in the area.
\end{abstract}

Keywords:

Rail infrastructure; Road Infrastructure; Literature review

\section{INTRODUCTION}

Productivity development in the construction industry, such as road and rail infrastructure, has been weak for a long period of time, possibly due to the traditional form of contracting used. In the recent years, these traditional forms for operation and maintenance have caused increased costs, and thus resulted in an increased interest for new contracting types [1-2]. Construction contracts are currently used to a large extent in Sweden, but this type of contract has shortcomings concerning weak incentives for the development of procedures [3]. Interviews with managers at the Swedish Transport Administration, formerly the Swedish Rail Administration (see more detailed information in Section 3), are in line with this argument, which claims that the major obstacles for technical development, as well as the limited room for innovation, are due to over-detailed specifications of how to do things [4]. This gives the procurer a reason to design the contracts to produce more incentives for cost efficiency [3]. It is also in the strategy of the Swedish Transport Administration to improve the cost efficiency of maintenance by improving the conditions already in the development phase, and to perform maintenance as efficiently as possible considering the entire life cycle of the products [5] . One way of doing this could be with another type of contracting. Performance contracting gives better incentives for contractors to develop the product by e.g. finding a better balance between building and maintaining costs [6]. The contractor is responsible for delivering an agreed upon function and can decide how this should be done, as well as for weighing building costs against future maintenance cost which should provide a cheaper solution for both procurer and contractor [6]. This type of contracting, when the customer only pays when outcomes have been delivered instead of the traditional payment for tasks and activities, is also called Product Service Systems, or PSS [7]. A more extensive review of this type of contracting can be found in Section 4.

This is the starting point of the DORIS (Development of (Integrated product service) Offerings for Rail Infrastructure Systems) project which was launched in cooperation with the Swedish Transport Administration to investigate the possibility for PSS contracts within the rail infrastructure in Sweden. This paper is based on parts of the initial literature study [8] and has the following objective.

\subsection{Objective}

The objective of this paper is to, through a literature study, investigate what has been published in the area of PSS contracts for rail and road infrastructure, as well as to look into the current state of rail infrastructure procurement. This gives the following research questions:

- RQ1: What types of contracts are currently used when procuring rail and road infrastructure?

- RQ2: To what extent are PSS contracts used for rail and road infrastructure?

- RQ3: In what way are the PSS contracts for rail and road infrastructure documented?

\subsection{Limitations}

The examples of PSS contracts presented are mostly implemented in Scandinavia, with the exception of one example from the UK. Furthermore, issues concerning performance requirements and measures will not be addressed in this paper, even though these issues represent major challenges for these contracts.

\subsection{Outline of the paper}

This paper starts with a description of the method used, and subsequently presents the PSS concept. Next, examples of PSS contracts for rail and road infrastructure are presented, followed by the discussion, conclusion and suggestions for further research.

\section{METHOD}

The starting point for the literature study was an introductory interview with an employee at the Swedish Transport Administration, one well informed with the working process in the organization. The goal was to gain sufficient knowledge within the area to start searching for literature for this study.

Literature reviewed includes several different kinds of sources: scientific articles, reports, homepages, master theses as well as 
doctoral and licentiate theses. The information has, when it was possible, been triangulated using different sources. However, the information concerning the use of PSS contracts for rail and road infrastructure was limited to just a few sources. This could imply that the information was biased, but most of the information was retrieved from the Swedish National Road and Transport Research Institute. No geographical limits were used when searching for literature; instead, the search included literature from several continents, even though some of it is not included in this paper. This is partly due to the difficulty in judging the quality, and partly since the conditions for the contracts were far from the ones in Sweden, and therefore not relevant in this study.

\section{THE CURRENT SITUATION FOR PROCUREMENTS OF RAIL AND ROAD INFRASTRUCTURE IN SWEDEN}

The Swedish Rail Administration is responsible for $80 \%$ of the total rail system in Sweden [9]. Since 2001, the Swedish Rail Administration has exposed its maintenance contracts to competition, and by the end of $2009,88 \%$ (measured in track distance) of the maintenance had been exposed to competitive procurement [10]. Furthermore, competitive procurement has resulted in reduction in costs for maintenance, but despite this, maintenance costs are increasing, and in 2008 maintenance costs and reinvestment cost made up over $50 \%$ of the cost for new investments.

It was concluded in a doctorial thesis [11] from 2006 concerning the former Swedish Rail Administration that there has not been significant pressure on the organization, internally or externally, to use life-cycle environmental management, and the work has been focused on environmental issues found locally, and not on life-cycle perspectives. Furthermore, the author states that the railway needs to adopt new perspectives to start working with environmental management of the products, and to set environmental requirements already when designing new products, i.e.before introducing them in the material supply chain.

\subsection{Construction contracts}

Construction contracts are the most common contracts within the infrastructure construction industry in Sweden [12]. The concept is based on the procurer specifying what, how and how much for the project [6]. This includes the choice of technology, materials and functions, and the tenders are made in unit prices with the choice of tender mainly based on the lowest price [2]. Construction contracts imply that the procurer carries all the risk, and a maximum roof for the price is set which does not create any incentives for the contractors to make the processes more efficient; instead, they benefit from reaching the maximum sum [6]. Furthermore, the author states that it also increases the incentives for the contractors to make additional orders to increase their profitability, or even to present a low tender and then make the money on the additional orders.

\subsection{Service contracts}

The Swedish Transport Administration has since 2005 used performance contracts for its maintenance [5], meaning that "...the Swedish Rail Administration procures a functionality of the track that has been set in advance. The contractor subsequently decides what measures to take with respect to the performed reviews and regulations for maintenance." [13] The length of the contracts is 5 years, with an additional 2 years option with bonuses for improvements, such as a lower number of errors, and with penalties when the contractor has not reached the levels of e.g. delays [5].

\section{PRODUCT SERVICE SYSTEM: ONE CONCEPT, SEVERAL NAMES}

The focus for this paper is PSS contracts where the procurer requests a function instead of a specific execution [12]. This kind of functional buying/selling has many different names, and during this literature study several different names for the concept of buying a function have been revealed. The most commonly occurring are presented in Table 1. The concepts in the tables have no intergroup order.

\begin{tabular}{|c|c|c|}
\hline Name & Definition/description & $\begin{array}{l}\text { Reference } \\
\text { (Name, } \\
\text { year, } \\
\text { page) }\end{array}$ \\
\hline $\begin{array}{l}\text { Outcome- } \\
\text { based } \\
\text { contracting }\end{array}$ & $\begin{array}{l}\text { ".... contracting mechanism that } \\
\text { allows the customer to pay only } \\
\text { when the firm has delivered } \\
\text { outcomes, rather than merely } \\
\text { activities and tasks." }\end{array}$ & $\begin{array}{l}\text { Ng et al., } \\
2009, \text { p. } 1 \\
{[14]}\end{array}$ \\
\hline $\begin{array}{l}\text { Performance- } \\
\text { contracting }\end{array}$ & $\begin{array}{l}\text { "The contract terms are based on } \\
\text { that future users are given access to } \\
\text { some specific services, not on the } \\
\text { contractor fulfilling technical } \\
\text { specifications: it is the performance } \\
\text { of the asset over the contracting } \\
\text { period that matters." }\end{array}$ & $\begin{array}{l}\text { Nilsson } \\
\text { et al., 2006, } \\
\text { p. } 7[3]\end{array}$ \\
\hline $\begin{array}{l}\text { Performance- } \\
\text { based } \\
\text { contracts }\end{array}$ & $\begin{array}{l}\text { "...are about contracting on } \\
\text { performance, rather than tasks or } \\
\text { outputs by the service provider." }\end{array}$ & $\begin{array}{l}\mathrm{Ng} \text { and } \\
\text { Yip, 2009, } \\
\text { p. } 207 \text { [15] }\end{array}$ \\
\hline $\begin{array}{l}\text { Functional } \\
\text { sales }\end{array}$ & $\begin{array}{l}\text { "The customer purchases a function } \\
\text { and the hardware plus service } \\
\text { includes the totality of activities that } \\
\text { enable the customer to benefit from } \\
\text { a total functional provision." }\end{array}$ & $\begin{array}{l}\text { Alonso- } \\
\text { Rasgado } \\
\text { et al., 2004, } \\
\text { p. } 515[16]\end{array}$ \\
\hline $\begin{array}{l}\text { Solutions } \\
\text { projects }\end{array}$ & $\begin{array}{l}\text { “...solutions projects usually include } \\
\text { the responsibility for the provider to } \\
\text { manage, resource, support and } \\
\text { improve the delivery of the solution } \\
\text { through the life of the product or } \\
\text { system in use." }\end{array}$ & $\begin{array}{l}\text { Brady } \\
\text { et al., 2005, } \\
\text { p. } 364 \text { [17] }\end{array}$ \\
\hline $\begin{array}{l}\text { Performance } \\
\text { contracts }\end{array}$ & $\begin{array}{l}\text { "Performance Contracts are defining } \\
\text { a product and it is up to the } \\
\text { contractor how to achieve this. } \\
\text { Therefore, work selection, design } \\
\text { and delivery are all his } \\
\text { responsibility." }\end{array}$ & $\begin{array}{l}\text { Zietlow, } \\
\text { 2005, p. } 3 \\
{[18]}\end{array}$ \\
\hline $\begin{array}{l}\text { Product } \\
\text { Service } \\
\text { System, PSS }\end{array}$ & $\begin{array}{l}\text { "a marketable set of products and } \\
\text { services capable of jointly fulfilling a } \\
\text { user's need" }\end{array}$ & $\begin{array}{l}\text { Goedkoop } \\
\text { et al., } 1999 \text {, } \\
\text { p. } 18[7]\end{array}$ \\
\hline $\begin{array}{l}\text { Integrated } \\
\text { Product } \\
\text { Service } \\
\text { Offerings, } \\
\text { IPSO }\end{array}$ & $\begin{array}{l}\text { "...from a lifecycle perspective, to } \\
\text { offer and optimise a solution with a } \\
\text { combination of products and } \\
\text { services that satisfies an identified } \\
\text { customer need, and at the same } \\
\text { time increases the suppliers' } \\
\text { competitiveness. " }\end{array}$ & $\begin{array}{l}\text { Lindahl } \\
\text { et al., 2006, } \\
\text { p. } 1-2[19]\end{array}$ \\
\hline
\end{tabular}

Table 1: Different names for performance-based contracts. 
From this table it can be concluded that even though the names of the concepts differ they still include the same content, namely that the focus is on the output, and not on how the output is achieved. In this paper, the concept will be called Product Service System, or PSS, since this is the most common name of the concept. The PSS for the infrastructure includes planning, construction and subsequently maintenance of the construction when the usage phase has started [12].

\subsection{PSS characteristics}

PSS offerings have a life-cycle perspective, and the combination of products and services can be combined into an optimized solution for the customer, as well as to give the manufacturing company the possibility to have control over the product throughout its whole lifecycle $[17,19]$. PSS provides the supplier with a possibility to increase the value of the solution for the customer by integrating components in new ways [17], and is thereby a driver for the development of a technical solution [19]. This provides incentives for the supplier to realize a more economical and environmental development when considering the whole life-cycle [19]. Companies acting in a mature industry can use the PSS as a growth strategy and compete with their core competence rather than with physical assets [20]. The author also states that PSS requires a closer and improved relationship with the customer, and the customer no longer has to be the owner of the product.

\section{PSS FOR RAIL AND ROAD INFRASTRUCTURE}

This section provides examples of projects fulfilling all or parts of a PSS contract for road or rail infrastructure.

\subsection{PSS for rail infrastructure}

The two rail projects reviewed, as seen in Table 2, are collected from Sweden and the UK, and differ considerably in their content.

\section{Arlandabanan, Sweden}

Arlandabanan is a $20 \mathrm{~km}$ long railroad section with double tracks, a $7 \mathrm{~km}$ tunnel and several underground stations between the city of Stockholm and Arlanda airport [21]. The winning tender for this Public-Private Partnership, PPP,contract was a consortium constructed by six companies from several different countries [22]. The consortium later formed the company $A$-train $A B$ to finance, build and subsequently run the train traffic. Construction began in 1995 and was finished in 1999, when the ownership of the facility was transferred back to Arlandabanan Infrastructure $A B$, former $A$ banan $A B$. At the same time, A-train got the right to use the tracks for traffic until 2040, as well as the responsibility to run and maintain the facility during the same time period. [21] The ticket revenues from the end customers serve as revenues for A-train in this contract [12]. Arlandabanan Infrastructure $A B$ has the possibility to cancel this agreement in 2010 if A-train is not fulfilling the requirements of the contract [21] .

Two thirds of the construction costs were funded by the consortium, while the last third was a conditional loan from the government. All the income risk was carried by the consortium, as well as most of the cost risk in the project. [23] A-train had the right to a penalty from Arlandabanan Infrastructure $A B$ in case it would not be possible to construct a double track within the time that was agreed, since this would delay the traffic start, and also for other issues such as discovery of archeological findings or incorrect technical information [24]. A-train got the freedom to balance the cost for the initial investment and the cost for maintenance, and subsequently chose to use another solution for the tracks than the original idea of the procurer [25].

\section{The Northern Line, UK}

In 2003, three long-term contracts including maintenance and upgrading of infrastructure of the London Underground network were signed dividing the network into three parts e.g. the part including the Jubilee, the Northern and the PiccadillyLines. These PPP contracts spanned over 30 years, with opportunities to review the contracts and requirements every 7.5 years [26]. For the Northern Line, the contract included the leasing of the trains and an area of 50 stations, and full responsibility for the design, manufacturing and cleaning of trains and related equipment [27]. In addition, the contract was formulated so that $80 \%$ consisted of capital works and $20 \%$ of service elements the first years, while the service made up $100 \%$ of the total in the fifth year and beyond.

The contracts were output-specified, and the required performance levels were measured with the following three factors [26]:

- Availability, counting delays and disruptions lasting longer than two minutes.

- Capability of the line.

- Ambience, measuring the quality of the customers' travelling environment.

These measurements were all set in 2003 , before the contracts started, and a level of around $5 \%$ worse than the historic data of the London Underground was decided to be the benchmark for the first five years, and then subsequently become more challenging with time [26]. The report also states that bonuses and penalties are used as additional adjustment for the performance, and liabilities for environment and safety are included. Furthermore, the same report claims that the availability for the JNP Lines have improved on the whole since the start in $2003 / 2004$. This has, on the other hand, not been consistent for all the lines, e.g. the availability measure for the busy Northern line was $48 \%$ worse than the benchmark in 2005/2006 [28]. Furthermore, the article states that the parties then agreed upon a change in the contract to solve the problem, i.e. the program for renewable the tracks was accelerated and initiated two years earlier than stated in the initial contract.

\begin{tabular}{|l|c|c|c|}
\hline Project & Content & Length & Payment \\
\hline $\begin{array}{l}\text { Arlanda- } \\
\text { banan, } \\
20 \mathrm{~km} \text { (SWE) }\end{array}$ & $\begin{array}{c}\text { Finance, } \\
\text { build, } \\
\text { operate and } \\
\text { maintain. }\end{array}$ & 45 years & $\begin{array}{c}\text { Contractor built } \\
\text { the tracks and is } \\
\text { now leasing them. } \\
\text { Ticket revenues. }\end{array}$ \\
\hline $\begin{array}{l}\text { The Northern } \\
\text { Line, } \\
\text { (UK) } \text { stations }\end{array}$ & $\begin{array}{c}\text { Design, } \\
\text { manufacture } \\
\text { and service. }\end{array}$ & 30 years & $\begin{array}{c}\text { Leasing contract } \\
\text { based on a } \\
\text { guaranteed } \\
\text { number of trains } \\
\text { and performance } \\
\text { improvement. }\end{array}$ \\
\hline
\end{tabular}

Table 2: Reviewed contracts for rail infrastructure.

\subsection{PSS for road infrastructure}

Three Scandinavian road contracts are reviewed in this paper. Table 3 illustrates their differing financial solutions.

\section{Norrortsleden, Sweden}

An ongoing contract for the Swedish Transport Administration includes design, construction and then maintenance for 15 years. The project comprises $7 \mathrm{~km}$ of highway, including a tunnel and several road bridges. The public procurement process started in 2003, and three companies sent in their tenders. The differences in price for the contracts concerning the design and construction were minor, while there were significant differences in the pricing concerning the maintenance phase. The contractor built the 
construction during a period of 3.5 years (2005-2008), and is currently responsible for maintaining it. [29]

The technical requirements were mostly formulated as functional requirements; examples follow below, translated directly from Swedish [29]:

- "The road and the tunnel should be designed for a dimensioned speed of $90 \mathrm{~km} / \mathrm{h}$."

- "The road body,..., should by the transfer have a remaining lifespan (residual value) of at least 25 years."

- "The design of the bridges should follow an overall coherent formation concept for the whole of Norrortsleden."

During the construction phase the role of the procurer was one of advisor, since the operation was led by the contractor [30]. The report also refers to the fact that the two organizations were built to mirror each other to ease the cooperation. A fixed annual payment for the construction with a special arrangement for the tunnels, where the contractor classifies the quality of the mountain as well as what activities are needed, serves as guidance for the pricing, and any sums above or below this price are shared by the two parties [29]. Furthermore, the reports states that the compensation to the contractor for the maintenance phase is paid as a fixed sum every year; this sum is adjusted by an index based on nine weights specified in the contract, e.g. amount of traffic [29]. The risk of the project was decided to be assign to the one that was in the best position to manage it, in this case the contractor [30].

\section{E18, Finland}

In Finland in 2005, a performance contract was signed for a $51 \mathrm{~km}$ road section, including tunnels and bridges, concerning design, construction, operation and finance[3, 31]. The section, MuurlaLohjanharju, is a cooperation between the public and private sectors, with the Finnish Road Authority buying the entire project from a consortium [32] .

The tenders of the contract were, apart from the price, judged on e.g. experience of similar projects, preliminary plan for building and maintenance, plan for reassuring quality, plan for handling technical disturbances and the contractors' financial situation [3]. The authors claim these parameters influenced the pricing by plus or minus $10 \%$. The contract lasts until 2029 , equal to 21 years, and as from the opening of the road in 2008 the Finnish Road Authority pays a service fee depending on the availability and service level of the road including several quality criteria [31-32]. The fee is connected to a yearly index regulation, and the procurer carries the risk for an increase in price for different components used [3]. The authors further state that the maintenance costs are based on a calculated value for the extent of the traffic, and the contractor does not carry the risk for an increase in traffic. Furthermore, they mean that there is a deduction in fee e.g. if the availability is not satisfactory, and the traffic safety is measured every year to give the contractor incentives to work for accident reduction. The report also states that innovations that bring a decreased number of accidents are rewarded, while an increase in the yearly accident count results in a deduction from the yearly payment. Furthermore, the contractor is also refunded for the initial investment when the road is ready for traffic, providing incentives for fast opening. At the end of the contract period, the road section will be transferred and Finnra will attain control [31]. This will be done without any additional fees, and the road section must be in the condition agreed upon [32].

\section{E39, Norway}

Three road projects have been procured by PPP contracts [23]. The three projects were $27 \mathrm{~km}, 38 \mathrm{~km}$ and $38 \mathrm{~km}$ respectively, and they have similar characteristics so the description will be limited to one of them, namely the first section, E39 Klett- Bårdshaug [33]. Four potential tenders were competing for the contract [23]; however, the potential contractors had to apply for a pre-qualification questionnaire to determine that the contractors fulfilled requirements such as necessary technical and professional knowledge, financial strength to complete the project, documented experience and a list of reference projects [33]. The construction started in 2003 and two years later the road opened, two months before the scheduled time [23]. The authors also state that the contractor is responsible for financing, building and maintenance over a period of 25 years, and after that the Norwegian public roads administration take over the maintenance.

The responsibility of the contractor is the safety and the availability of the road and for standards such as environmental standards [33]. Furthermore, the report points out that the contract includes more detailed requirements, such as quality and performance standards and quality routines for which the NPRA can survey to make sure they are being followed. The public part carries risk for events that the project company has no or minor possibility to influence, such as changes in legislation, while risks related to financing, planning, construction, operation and maintenance are allocated to the project company according to the report.

The project company receives an annual payment depending on the availability, performance, safety and amount of traffic on the road, but out of these, availability and performance are the major contributions to the payment, while the rest are seen as additional payments [33]. These traffic payments increase with increased traffic, as well as the safety payments, which are seen as a bonus related to the number of and the character of the accidents that occur compared to an equivalent average road [23]. Furthermore, the authors state that the Norwegian public roads administration has introduced a toll system for the roads for the first 15 years, from which the income will cover part of the costs for the project.

\begin{tabular}{|c|c|c|c|}
\hline Project & Content & Length & Payment \\
\hline $\begin{array}{l}\text { Norrorts- } \\
\text { leden, } \\
7 \text { km (SWE) }\end{array}$ & $\begin{array}{l}\text { Design, } \\
\text { construct } \\
\text { and } \\
\text { maintain. }\end{array}$ & 15 years & $\begin{array}{l}\text { Fixed yearly sum } \\
\text { based on index } \\
\text { Special payment } \\
\text { model for tunnels. }\end{array}$ \\
\hline $\begin{array}{l}\text { E18, } \\
51 \mathrm{~km} \text { (FIN) }\end{array}$ & $\begin{array}{l}\text { Finance, } \\
\text { design, } \\
\text { construct, } \\
\text { and } \\
\text { maintain. }\end{array}$ & 21 years & $\begin{array}{l}\text { Initial investment } \\
\text { and service fee to } \\
\text { contractor } \\
\text { depending on } \\
\text { availability and } \\
\text { service level of } \\
\text { the road. Adjusted } \\
\text { for change in } \\
\text { traffic. }\end{array}$ \\
\hline $\begin{array}{l}\text { E39, } \\
27 \mathrm{~km} \text { (NOR) }\end{array}$ & $\begin{array}{l}\text { Finance, } \\
\text { design, } \\
\text { construct, } \\
\text { and } \\
\text { maintain. }\end{array}$ & 25 years & $\begin{array}{c}\text { Payment } \\
\text { depending on } \\
\text { availability and } \\
\text { standard of the } \\
\text { road. Toll system } \\
\text { for procurer. }\end{array}$ \\
\hline
\end{tabular}

Table 3: Reviewed contracts for road infrastructure.

\section{DISCUSSION}

This concluding discussion has the ambition of answering the research questions posed in the introduction by contrasting reviewed contracts. 


\subsection{What types of contracts are currently used when procuring rail and road infrastructure?}

Currently, construction contracts are the most common way to procure rail and road infrastructure in Sweden [12], while maintenance contracts are mostly a type of performance contract spanning over five years with specified functional requirements [5]. This is a short time period compared to the life-cycle of rail tracks, which is why PSS contracts would be of interest instead.

\subsection{To what extent are PSS contracts used for rail and road infrastructure?}

The two examples reviewed for rail infrastructure have both similarities and differences. The Arlandabanan project included both building the tracks and later maintaining them, as well as operating the train traffic [21]. The Northern Line project, on the other hand, focused on the actual trains and reinvestment, maintenance and operation of them [27]. Both of the contracts involve the operating of the traffic, but only in the case of Arlandabanan is the construction of the tracks included. The Northern Line contract has an outputspecified performance level where availability is emphasized when it comes to payment for the contractor [26]. For Arlandabanan, it is a totally different case since that consortium receives its revenues from the end customers [25] and not the procurer. While the Northern Line contract was formulated as a PSS contract, it is not known how specified the contract for Arlandabanan was, even thought there seems to have been margins for flexibility for A-train when formulating their solution [25]. Other similarities are the long time period for the contracts, 45 years for Arlandabanan [21] and 30 years for the Northern Line [26]. This differs a lot from the time periods currently used for maintenance contracts in Sweden.

The three road contracts reviewed differ significantly in size when measured in kilometers as well as the payment mechanism. The E18 and the E39 both have an output-specified payment where the fee depends on availability and performance or service level [3233]. The E18 contract also includes the fulfillment of some quality criteria in the payment model, and this is also the case for the E39 [32-33], but this model is far from the fixed yearly sum that the payment for the Norrortsleden consists of, where only an adjustment is made by an index [29]. All three contracts do however make adjustments for changes in traffic, since this is something the contractor cannot affect, meaning there has to be some flexibility in the contracts making it possible for the contractor to carry the risk.

All contracts reviewed in this paper seem to have the life-cycle perspective that is included in a PSS contract [19] as well as the combination of products and services [19] that is required. The type of products and services differs from different contracts, even though they are implemented in the same industry. In four of the five cases the procurer owns the product, the rail tracks, while in the fifth case it is the contractor who owns the product, the trains, which is in line with the characteristics of a PSS saying that it is not necessarily the customer who gets the ownership of the product [34]. However, even though most of the contracts are outputspecified there are still more detailed requirements from the buyer.

\subsection{In what way are the PSS contracts for rail and road infrastructure documented?}

Little has been done and consequently documented in the area of PSS contracts for road and rail infrastructure. This is especially true for the rail infrastructure, where few projects have been realized. For the infrastructure that has in fact been procured with a PSS type of contract, the information concerning the implementation includes reports and not articles published in scientific journals. These reports consist of information concerning the planning and building of the infrastructure, but in general the contracts have not been in place long enough to be evaluated. The maintenance phase of the contracts can span over decades, implying a complete evaluation will not be realized in the near future since most of the contracts reviewed in this study have recently transitioned from the building to the maintenance phase. Something worth mentioning is that the reports are mainly financed by the governmental organizations, in the case of Sweden by the Swedish Transport Administration, showing that there is in fact an interest in these types of contracts from the procurer side.

\section{CONCLUSION AND FURTHER RESEARCH}

Contracting for rail and road infrastructure in Sweden is done using traditional construction contracts, and with maintenance contracts using a small degree of performance dimension. A general conclusion from this literature study is that the PSS contracts used for road infrastructure are more developed than the ones for rail infrastructure. This could be due to the complexity of the rail structure, implying there are more issues to handle than when building roads. It is therefore likely that the rail infrastructure can benefit from the experience from the road infrastructure. On the other hand, the road contracts are output-specified, but still have elements of more detailed requirements.

The lack of publications, in combination with interest from the industry in this field, implies that there is a gap in the area where research is needed both to facilitate the use of the contracts but also to move the research forward. The next step in the DORIS project is to conduct an interview study focusing on possibilities and challenges concerning PSS contracts for rail and road infrastructure in Sweden. The respondents will consist of the Swedish Transport Administration, contractors and track design actors. This will be followed by a quantitative study focusing on the environmental and economical advantages and disadvantages with PSS contracts for rail and road infrastructure.

\section{ACKNOWLEDGMENTS}

The authors would like to thank the Swedish Transport Administration for financing the study.

\section{REFERENCES}

[1] Nilsson J.-E., (2009). Nya vägar för infrastruktur. Stockholm: SNS Förlag.

[2] Hedström R., Ihs A., Sjögren L., (2005). Funktionsupphandling av väg- och banhållning, Problem och möjligheter. Linköping: Swedish National Road and Transport Research Institute.

[3] Nilsson J.-E., Ihs A., Leif S., Wiman L.G., Wågberg L.-G., (2006). Funktionsupphandling. Sammanfattning av kunskapsläget och rekommendationer för fortsatt forskning. Linköping: Swedish National Road and Transport Research Institute.

[4] Stenbeck T., (2004). Incentives to Innovations in Roas and Rail Maintenance and Operations. Stockholm: Royal Institute of Technology.

[5] Riksrevisonen, (2010). Underhåll av järnväg.

[6] Nilsson J.-E., Bergman M., Pyddoke R., (2005). Den svåra beställlarrollen. Stockholm: SNS Förlag.

[7] Goedkoop M.J., Halen C.J.G.v., Riele H.R.M.t., Rammens P.J.M., (1999). Product Service systems, ecological and economical benefits. PricewaterhouseCoopers N.V./Pi!MC/Storrm C.S./Pre Consultants, Netherlands. 
[8] Lingegård S., (2010). PSS contracts for rail and road infrastructure - a literature study, LIU-IEI-R-- 10/0112--SE. Linköping: Department of Management and Engineering.

[9] Banverket, (2008). Banverkets årsredovisning 2008. Borlänge: The Swedish Rail Administration.

[10] Banverket Produktion, (2009). Banverket Produktion Årsrapport 2009. Banverket Produktion.

[11] Svensson N., (2006). Life-Cycle Considerations for Environmental Management of the Swedish Railway Infrastructure [Doctorial]. Linköping: Linköping University.

[12] Nilsson J.-E., Pyddoke R., (2007). Offentlig och privat samverkan kring infrastruktur- en forskningsöversikt. Linköping: Swedish National Road and Transport Research Institute.

[13] Banverket, (2009). Banverket årsredovisning 2009. The Swedish Rail Administration.

[14] Ng I.C.L., Maull R., Yip N.,(2009). Outcome-based contracts as a driver for systems thinking and service-dominant logic in service science: Evidence from the defence industry. European Management Journal.27(6):377-87.

[15] Ng I., Yip N., (2009). Identifying Risk and its Impact on Constracting Through a Benefit Based-Model Framework in Business to Busniess constracting: Case of the denfence industry. 1st CIRP Industrial Product-Service Systems (IPS $\left.{ }^{2}\right)$ Conference. Cranfield University. p. 230.

[16] Alonso-Rasgado T., Thompson G., Elfström B.-O.,(2004). The design of functional (total care) products. Journal of engineering design.

[17] Brady T., Davies A., Gann D.M.,(2005). Creating value by delivering integrated solutions. International Journal of Project Management.23(5):360-5.

[18] Zietlow G., (2004). Implementing performance-based road management and maintenance contracts in developing countries-an instrument of German technical cooperation. German development cooperation.

[19] Lindahl M., E. Sundin, A. Öhrwall Rönnbäck, G. Ölundh, J. Östlin,, (2006). Integrated Product and Service Engineering the IPSE project. Changes to Sustainable Consumption, Workshop of the Sustainable Consumption Research Exchange (SCORE!) Network (wwwscore-networkorg), supported by the EU's 6th Framework Programme. Copenhagen, Denmark.

[20] Mont O.K.,(2002). Clarifying the concept of product-service system. Journal of Cleaner Production.10(3):237-45.

[21] Arlandabanan Infrastructure AB, (2010). Arlandabanan Infrastructure.

[22] Arlandaexpress AB/A-train, (2010). Arlanda express- About us.

[23] Arnek A., Hellsvik L., Trollius M., (2007). En svensk modell för offentlig-privat samverkan vid infrstrukturinvesteringar. Linköping: Swedish National Road and Transport Research Institute.

[24] Enberg N., Hultkranz L., Nilsson J.-E., (2004). Arlandabanan, en uppföljining av samhällsekonomiska aspekter på en okonventionell projektfinansiering några år efter trafikstart. Swedish National Road and Transport Research Institute.

[25] Nilsson J.-E., (2008). Upphandling, avtalsutformning och innovationer. Borlänge: VTI.
[26] London Underground, (2010). Transport of London, PPP \& Performance Report 2009/2010, Report from the financial year ending March 31 2010. London.

[27] Harding A., Watts P.,(2000). The Northern Line Train Service Contract. Proceedings of the Institution of Mechanical Engineers -- Part F -- Journal of Rail \& Rapid Transit.214(1):55-60.

[28] (2006). Three years on, and the PPP presents a MIXED picture. Railway Gazette International.162(10):669-74.

[29] Förnyelse i anläggningsbranschen (FIA), (2005). Slutrapport kortversion: Funktionsentreprenad Täby Kyrkby-Rosenkälla. Förnyelse i anläggningsbranschen.

[30] Förnyelse i anläggningsbranschen (FIA), (2008). Funktionsentreprenad i Täby Kyrkby-Rosenkälla, byggskedet. p. 22.

[31] Lehtinen P., Tuomisto T., Mikkola I.,(2006). Finland paves roads for future PPPs. International Financial Law Review.25:2:53-5.

[32] Vägförvaltningen (Finnra), (2005). Riksettan-till födel för alla, Motorvägen E18 Muurla-Lojo. The Finnish Road Administration.

[33] Norwegian Public Roads Administration, (2001). PPP-project E39 Klett-Bårdshaug.

[34] Mont O.K.,(2002). Claryfying the concept of product-service system. Journal of Cleaner Production.10:237-45. 